\title{
The Indonesian Syntactic Structure Interfere into English Sentences: An Interlanguage Study
}

\author{
Bahar1, Dahlia Husain², Eko Aprianto $^{3}$ \\ ${ }^{1}$ Universitas Fajar Makassar, Sulawesi Selatan, Indonesia \\ ${ }^{2}$ Faculty of Humanities, University of Muhammadiyah Gorontalo, Indonesia \\ ${ }^{3}$ Informatika dan Komputer Indonesia College (STIKI) Malang, Indonesia \\ baharsetiawan@unifa.ac.id
}

\begin{abstract}
The reason for conducting this research was based on consideration that university students majoring in English should be at the level where their English is considered good. Unfortunately, students still made errors in both spoken and written form. In this study, 20 students of English Department at Fajar University enrolled which were taken by total samplingmethod. This research is aimed to provide useful information particularly as referencefor English teachers, lecturers and curriculum developers about the extent of theIndonesian syntactic structure that interfere the students in making English sentence.A mix method was applied in which the data was analysed both qualitatively andquantitatively. The conclusion of the result shows that the students still have problemsin making English sentences. They still make errors in forming English sentences thatbased on the Indonesian form. Further, the most errors are found are the error of omissions. It is proven by the findings that the interference of Indonesian syntactic formis the main cause of student's error in making English sentence.
\end{abstract}

Keywords: interfere; Indonesian syntactic structure; translation

\section{Introduction}

Mastering English language has become more than just a necessity. These days, the ability to speak the language is prioritized among different subject and major due to its function as a lingua franca. Nonetheless, one of the foremost problems that appear is constructing grammatically correct sentence that can be understood by others. Effective communication can happen when well-constructed sentences are used. as a tool of communication, English language needs a system that must be used by the user, in order that communications can be done efficiently and effectively (Ruru, 1980). However, the fact shows us some mistakes in our daily language activity; those are phonology, lexis, syntax, and semantics.

Errors are the flawed side of learner speech or writing. Those are part of conversation or compositions that deviate from some selected norm of nature language (Daulay et al, 1982). The researcher believes that living in multilingual situation will influence the students in learning and acquiring a foreign language (English). The influence could be an interference caused by syntactic structure of Indonesian language. This kind of interference is quiet enormous. The habits of students to construct ungrammatical English sentences are visible. They sometimes tend to construct English sentences under the influence of their habits in forming Indonesian sentences. They sometimes make English sentences based on the Indonesian form. Similarly, difficulties faced by the L2 learners may be resulted from the differences of the target language from the source language (Dewaele, 2000). These differences may resulted as negative transfer or so called interference.

Errors analysis is a part of interlanguage study. Errors analysis focuses on the errors for produced by the second language learners in the target language. Error analysis is only concerned with the errors, where as Corder in the same book expresses that error analysis study 
is a study of the speech errors produced by the second language learners (Nurhaidi \& Roekhan, et al, 1980).

Traditionally, all forms which deviate from the rules of the target language are included as errors. Richard in Nurhadi and Roekhan limits the errors analysis as a study of the different ways between second learners and the native speakers in using the target language (Nurhaidi $\&$ Roekhan, et al, 1980). The different ways in using the target language by the second learners and native speakers are the errors analysis discussion.

The terms of errors classification applied for the analysis are clarified Omission errors are characterized by the absence of an item that must appear in a well-formed sentence of English.Addition errors are characterized by the presence if an item, which must not appear in well-formed sentence of English.Misformation errors are characterized by the in correct placement of morpheme or group of morpheme in sentence of English.Misordering errors are error which reflect the students' native language. Interlingual error is an error which reflects the students' native language. And last but not least is Intralingual error is an error which reflect students' competence a particular stage in their effort to study English as a foreign language. It is found within the structure of English itself and through reference to the strategy by which a foreign language is acquired and taught (Daulay et al, 1982).

In relation to the study, the so-called Interference means the overlapping of two languages and deviation from the norm of either language in such situation (Yerkes, 1989). In EnsiklopediaNasional Indonesia, it is stated that interference is confusion of language occurring because known language elements are taken into target language (Justini, 1995). The interference (in relation to the bilingualism) constitutes confusion between two language systems, if a system of the language mastered is applied to the system of the language learned, confusion or deviation will happen resulting in errors in using a language.

Indonesian learners of English as well as the students of ELS or English department are aware of their error in translating English sentences. However, they do not know the problem arise from their works. That's why the researcher is motivated to choose this topic. This particular study entitled "The Interference of Indonesian syntactic structure into English sentences: An Interlanguage Study"

Based on the previous background, the researcher was formulating research question as follow: 1) To what extent does the Indonesian syntactic structure interfere the students in making English sentence?

\section{Methodology}

In this study the researcher used descriptive quantitative and qualitative method. The advantage of using percentage as a tool to present such information lies upon its ability to display the extent of the aspects in focus (Arikunto, 2010). The researcher believes that identifying the frequency of the errors is not enough; therefore, it is necessary for the researcher to present the overall information in percentage.

The population of the research was English Department of Fajar University. The population itself was the fifth semester which consisted of one class only. The reason for these students to be the population of the research is due to the translation subject that they are currently taking this semester. The population consists of 20 students that are now in their fifth semester. All the students that was taken as the sample of the research are those that have Bahasa Indonesia as their L1. 
The sampling technique of the research was total sampling. It means that the researcher took all students of the fifth semester of Fajar University as the subject of this research. They consist of 20 students.

The researcher used translation task to describe the ungrammatical English sentences made as a result of influence of Indonesian structure (in this case, the students were provided with Indonesian sentences) then they were asked to translate them into English. The researcher here distributed 40 numbers of translation form that are divided into two meetings.

The data from the task were analyzed by applying error analysis technique, namely analysis the error of the sentences. The analysis of the data were conducted based on four kinds of errors, they are error of omission, error of addition, error of misformation and error misordering.

Yet, the procedure of analysis that was applied in this research was based on Ellis (Tarigan, 1992). The procedures itself include collecting samples of errors, identifying errors, interpreting errors, classifying errors and evaluating errors. Nonetheless, the last stage which was evaluating errors might not be the focus since it will only be the suggestion from the result of the research to the English teacher.

\section{Discussion}

In terms of errors of omission, the findings shows that most students made error of omission, the attitude to errors is they are all the result of the habits of the first language (Corder, 1981). Based on the findings, errors of omissions appeared to be the most common errors committed by the students. The findings of this research suggest that there are three types of error of omission that the students faced. Those are omission of determiner, error of subject and agreement, and omission of copula be. In terms of the Error of Addition, the students seems to create a form that does not exist in English nor in their mother tongue (bahasa Indonesia). There is also a form of error of misformation, in this type the errors appeared to be mostly in word formation in which the English form of word is Adjective + Noun, on the contrary, in Bahasa Indonesia, the form is Noun + Adjective.

In this present study, the first research question was to seek for the extent of the influence of indonesian syntactic structure in making English sentence. In order to answer this question, a set of translation tasks was given to the students. The findings indicated that the students still face a lot of errors in making English sentences whether as a part of interference or simply as a part of incomplete learning of English itself.

Errors are considered as the inevitable consequences of language learning, it is a part of the language learning that cannot be separated from the learning itself. Errors are viewed as more systematic and occurs all the time without the learners' realize. In contrast, mistake is non-systematic errors that only occur occationnaly with the learners realize it, as (Daulay, 1980) advocated that people cannot learn language without first systematically committing errors. For Indonesian students as an EFL learner, the problem of commiting errors in their learning becomes inavoidable. Such problems may come from a lot of reason, for example lack of practice, boring learning environment, or simply the absence of learners' interest in mastering the language itself.

The research that conducted by (Sinha, 2009) suggested that one of the major contributing factors of interference is that the medium of communication both in school and home were mostly held in L1, in this research, both the questionnaire and the interview were 
suggesting the exact same thing, that all the students were in L1 environment in their everyday life that hindered them to use or practice the L2.

Student's error in making English sentences is promoted by several big issues. The points that need to be sorted out here is the fact that these errors are cause not by one single problems, but so many. Thus some experts mentioned that error cannot be separated with learning, this identification might be one of the step that need to be done to overcome the problems of error or at least reduce the productions of errors made by the students. Among all the 4 types of errors that this study focused on, the errors of omissions seems to be the most dominant one. Not only become the most dominant one, the error of omissions are also divided into three main categories, which indicates that Indonesian learners does several types of errors of omission in their everyday production of English sentences. The findings revealed that most errors happens cause by inteference of the mother tonggue. Thus, it can be concluded that bahasa Indonesia does interfere students in making English sentences in which this interference hindered students to master the English langauge.

To the other extent, the interference of Indonesian syntactic structure into making English sentence can bring benefit to the students learning. This benefitial appears when positive transfer occured, in which the same rules are applied in both languages. Unfortunately, the researcher admitted that this is one of the limitation of this study that the translation task given to the students does not include any example of positive transfer. In regards to this study, the researcher focused on two things, to both identify and classify students' errors in making English sentences caused by interference and to revealed on the students' difficulties on dealing with the interference of mother language in making English sentence. For deeper analysis on the second question of the research, the following part describes thoroughly about such thing.

\section{Conclusion}

The $5^{\text {th }}$ semester students of Fajar University still have problems in making English sentences. They still make errors in forming English sentences that based on the Indonesian form. Based on the findings, the most errors are found are the errors of omissions. It is proven by the findings that the interference of Indonesian syntactic form is the main cause of student's error in making English sentence.

\section{References}

Arikunto, 2010. ProsedurPenelitianSuatuPendekatanPraktik. Penerbit Rineka Cipta. Corder, Sp. 1981. Error Analysis and Interlanguage, Oxford University Press, Great Britain. Dulay, Heidi et al. 1982. Language Two. New York: Oxford University Press, Inc. Great Britain. New York.

Dewaele, J.-M., \&Furnham, A. (2000). Personality and speech production: A pilot study of second language learners. Personality and Individual Differences, 28(2), 355-365.

Justini. 1995. Sentence Structure Types Produced by the Learners of Nirwana English Course Kolaka. A Thesis of Faculty of Letters UMI Ujung Pandang. Ujung Pandang.

Nurhaidi \& Roekhan, et al. 1980. Dimensi-Dimensi Dalam Belajar Bahasa Kedua. YA3 Malang, SinarBaru Bandung. Bandung.

Ruru, J.H. 1980. J.H 1980. Interference in English Language Learning Among Adult at the Language Centre of Hasanuddin University.Singapore. SEAME-RELC 
Sinha, A., Banerjee, N., Sinha, A. \& Shastri, R. K. (2009). Interference of first language in the acquisition of second language. Journal of Psychology and Counseling, 1(7), 117- 122.

Tarigan, H. G. and Tarigan, D. 1992. Pengajaran Analisis Kesalahan Berbahasa. Bandung: Angkasa Publisher.

Yerkes, David, et al. 1989. Webter's Encyclopedia Unabridged Dictionary of The English Language. New York. Portland House. New York. 